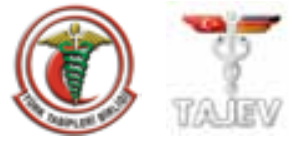

\title{
Uterine fibroids and current clinical challenges
}

\section{Uterin fibroidler ve güncel klinik tartısmalar}

\author{
Salama S. Salama', Gökhan S. Kıliç² \\ 'Department of Obstetrics and Gynecology, Division of Gynecologic Oncology, Baylor College of Medicine, Houston, \\ Texas, USA \\ ${ }^{2}$ Department of Obstetrics and Gynecology, University of Texas Medical Branch, Galveston, Texas, USA
}

\section{Abstract}

Uterine fibroids (UF) are the most common gynecological tumors in premenopausal women. Hysterectomy remains the major and definitive therapeutic option. Minimally invasive surgical techniques for performing hysterectomy have many advantages over laparotomy. Current drug therapies for UF remain unsatisfactory. Unquestionably, continued investigation of novel agents is necessary. The currently used drugs for UF treatment which exclusively modulate a single target, typically either the estrogen or progesterone signaling pathways, are limited in their therapeutic effects. By contrast, multi-target drugs which simultaneously modulate multiple critical hubs in the network of the signaling pathways underlying UF pathogenesis should achieve robust and durable therapeutic effects.

(J Turkish-German Gynecol Assoc 2013; 14: 40-5)

Key words: Uterine fibroids, hysterectomy, pathogenesis, drug therapy, multi-target drugs

Received: 20 February, 2013

Accepted: 25 February, 2013
Özet

Uterin fibroidler (UF) premenopozal kadınlarda en yaygın görülen jinekolojik tümörlerdir. Histerektomi başlıca tedavi seçeneğidir. Histerektomi uygulamasında minimal cerrahi yaklaşımların laparotomiye göre avantajlanı mevcuttur. UF tedavisinde kullanılan güncel ilaç tedavileri ise tatmin edici olmaktan uzaktır. Şüphesiz, yeni ajanlar için çalışmalar devam etmelidir. UF tedavisinde kullanılan, ya östrojen ya da progesteron yolakları gibi tek bir hedef üzerinden etki eden güncel tedaviler terapötik etkinlik konusunda yetersiz kalmaktadır. Bunların yanında, UF patogenezinde rol alan yolaklardaki birden çok kritik noktayı değiştiren çok hedefli ajanlar etkin ve uzun süreli terapötik etki sağlayacaktır.

(J Turkish-German Gynecol Assoc 2013; 14: 40-5)

Anahtar kelimeler: Uterin fibroid, histerektomi, patogenez, ilaç tedavisi, çok hedefli ilaçlar.

Geliş Tarihi: 20 Şubat 2013

Kabul Tarihi: 25 Şubat 2013

\section{Introduction}

Uterine fibroids (UF) are the most common gynecological tumors in premenopausal women $(1,2)$. The direct healthcare costs for UF management are estimated to be over $\$ 2$ billion annually in the United States. Hysterectomy remains the major and definitive therapeutic option, performed in more than 200,000 cases per year in the United States alone $(3,4)$. Unfortunately, hysterectomy results in permanent infertility of reproductive-age women. Surgical removal of fibroids alone, myomectomy, is associated with significant risks, such as massive intra-operative hemorrhage and distortion of the uterine cavity. In addition, the scar left on the uterus after myomectomy increases the chance of uterine rupture in future pregnancies. Even with myomectomy, UF have up to a $50 \%$ recurrence rate (5). Two relatively new modalities have been utilized for treatment of UF: myolysis and uterine artery embolization. Myolysis disrupts or abolishes the blood supply to the fibroid using bipolar or monopolar electrosurgery (6). The procedure is rarely performed and is not recommended for women who wish to become pregnant (7). Uterine artery embolization (UAE) is a procedure that uses radiologically directed injection of microspheres to block the blood supply to specific fibroids (8). At this point this method is also not recommended for women seeking future fertility. In addition, not all fibroids respond to UAE and it does not prevent recurrence of $\operatorname{UF}(9,10)$.

\section{Current medical therapies}

The current therapeutic approaches for UF treatment include gonadotropin-releasing hormone (GnRH) agonists which may reduce tumor volume by up to $40 \%$ in 3 months, with significant improvement in clinical symptoms $(11,12)$. However, GnRH agonists also cause a hypoestrogenic environment, which leads to serious side effects. Therefore, the use of $\mathrm{GnRH}$ agonists is limited to preoperative treatment of UF, both for myomectomy and hysterectomy in selected cases (13-16) Regrettably, the effects of GnRH agonists are short-lived and UF tend to rapidly re-grow, with recurrence of clinical symptoms after cessation of treatment (17). Another therapeutic strategy for UF treatment is inhibition/modulation of progesterone receptor (PR) transcriptional activity. This approach has been validated in preclinical and clinical studies and both antiprogestins and selective progesterone recep- 
tor modulators (SPRMs) have been shown to reduce tumor volume, control bleeding, and reduce pelvic pressure $(18,19)$. Unfortunately, there are adverse effects of long-term use of SPRMs, even at low doses, which include abnormal endometrial morphology, endometrial hyperplasia, and liver damage (20-22). These side effects have emerged as an impediment to the use of antiprogestins and SPRMs for all but short-term use as UF treatments. Recently, aromatase inhibitors (AIs) have been introduced as potential treatments; two case series have documented improved symptoms and reductions in the size of the tumors with the use of AIs $(23,24)$. In premenopausal women, AIs can be used for a short time before myomectomy or hysterectomy (25). Combined oral contraceptives, steroiddelivering vaginal rings, skin patches, Levonorgestrel-releasing intrauterine devices, progestin implants/injections, and progestin-only pills are currently used for improving symptoms in clinical settings. All of the current options have their limitations and contraindications for patient selection and efficacy (26, 27). Thus, current drug therapies for UF remain unsatisfactory. Unquestionably, continued investigation of novel agents is necessary.

\section{Current surgical therapies}

The first successful selected hysterectomy operation was performed in 1813 by Conrad Langenbeck via the vaginal approach, and today, after nearly two centuries, hysterectomy is the second most frequent surgery in women of reproductive age, with the first being cesarean section (28). Approximately 80000 hysterectomies are performed each year in the United Kingdom (UK), and over 600.000 in the United States (USA) (29, 30 ). Vast majority of these numbers (more than 70\%) are for benign indications such as menorrhagia (\%21), fibroids (33\%), pelvic pain (3\%) and uterine prolapse (28\%) (30).

The traditional surgical approach to hysterectomy involves a large abdominal incision, two to four day hospital stay and significant requirements for postoperative analgesia. Minimally invasive surgical (MIS) techniques for performing hysterectomy have many advantages over laparotomy, including reduced postoperative pain, shorter length of hospital stay, better cosmesis and quicker resumption of regular activity (31-38). The Nationwide Inpatient Sample of the Healthcare Cost and Utilization Project recently reported that abdominal hysterectomy was performed in $64 \%$ of cases, followed by the vaginal route in $22 \%$ of cases and the laparoscopic route in 14\% (34).

Improvements in minimally invasive techniques were introduced with 2005 Federal Drug Administration (FDA) approval of the da Vinci ${ }^{\circledR}$ Surgical System (Intuitive Surgical, Inc., Sunnyvale, CA) for use in gynecologic procedures. The da Vinci ${ }^{\circledR}$ Surgical System has some advantages compared to conventional laparoscopic surgery, such as three-dimensional (3D) vision, wristed instrumentation, improved dexterity, ergonomic positioning allows surgeon comfort with less hand fatigue and frustration, and eliminates the hand tremors (35-38). Currently, robotic-assisted hysterectomy is emerging as a new technique for hysterectomy and many of the general gynecologists have become to prefer robotic surgery for hysterectomy. For both general gynecologist and subspecialist including gynecologic oncologists and urogynecologists introduce to the robotic surgery usually through simple hysterectomies. In this chapter we aimed to describe the step by step approach to the simple hysterectomy performed with the da Vinci ${ }^{\circledR}$ Surgical System. The AAGL Advancing Minimally Invasive Gynecology Worldwide (formerly known as the American Association of Gynecologic Laparoscopists) released a statement in 2010 advising that "most hysterectomies for benign disease should be performed either vaginally or laparoscopically and that continued efforts should be taken to facilitate these approaches. Surgeons without the requisite training and skills required for the safe performance of vaginal hysterectomy $(\mathrm{VH})$ or laparoscopic hysterectomy (LH) should enlist the aid of colleagues who do or should refer patients requiring hysterectomy to such individuals for their surgical care" (39). In calling for a dramatic reduction in the number of abdominal hysterectomies, the AAGL position is in line with that of the American College of Obstetricians and Gynecologists (ACOG), issued in a committee opinion paper "Choosing the Route of Hysterectomy for Benign Disease" in November 2009 (39). ACOG supports the notion that LH and VH offer substantial advantages over abdominal hysterectomy (AH) (40). Taking these points into account, vaginal hysterectomies should be preferred for simple hysterectomies. In case vaginal hysterectomy is not feasible minimally invasive approach should be preferred. Gynecologist who cannot offer vaginal or MIS should consider referring the patients to surgeon who can perform these before offering open $\mathrm{AH}$.

After introducing robotic technology, hysterectomies performed utilizing MIS increased significantly in the last 5 years $(41,42)$. In our experience after introducing robotic program it takes one year to see switching number of cases from open to MIS hysterectomies which seems to be common trend nationwide (43). Currently there is a great deal of overlap in the indications of hysterectomies between laparoscopy and robotic surgery. However robotic surgery seems to have certain advantage over laparoscopy in obese patients and surgeries requires more dissection (endometriosis, pelvic-abdominal severe adhesions) (44, 45). Our prospective comparative study focused on the intra- and perioperative outcomes of 208 obese [Body mass index (BMI) $>30 \mathrm{~kg} / \mathrm{m}^{2}$ ) patients who underwent robotic-assisted hysterectomy (n: 51), laparoscopic hysterectomy (n: 24), and abdominal hysterectomy (n: 133) for benign indications at our institution (Unpublished data). We found that robot-assisted hysterectomy was associated with fewer intraoperative complications and estimated blood loss (EBL) and shorter length of hospital stay; there were no differences in postoperative complications, conversions to laparotomy. In our conclusion, we mentioned that robotic-assisted hysterectomy is safely and feasible procedure for obese patients with low morbidity, a shorter hospital stay, and comparable blood loss. Robotic surgery provides shorter learning curve commonly accepted opinion is approximately 20 cases required to reach to the steady state $(46,47)$. Compare to this steep learning curve in robotic surgery laparoscopy demands to higher number of cases to reach to the same level $(48,49)$. Conversely, the main disadvantages of the robotic surgery across applications are the cost, the large size of the robot and console and lack of tactile feedback or habits (50). 
A Cochrane review for surgical approaches to hysterectomy for benign gynecological disease found no definite evidence for favoring technique and stated that the surgical approach should be decided by the woman in discussion with her surgeon in light of the relative benefits and hazards (51). Recently, a new review was published by Cochrane about robotic surgery for benign gynecological disease and indicated that robotic surgery did not benefit women in effectiveness or in safety. However, this statement was limited by the small sample size (52). In literature, some authors have suggested vaginal approach primarily for hysterectomy $(11,12)$, some studies have showed the superiority of the MIS (53) and some have focused on roboticassisted hysterectomy and advised this approach for special individual cases $(17,54)$. There are only few comparative studies about robotic-assisted hysterectomy for benign indications and most of them are retrospective. Only three prospective comparative studies were published in the literature. The first one by Sarlos et al., second by Geppert et al., and last one was published by our group. The safety and feasibility of the robotic approach were reported in all three studies (55-58). The sample sizes were low in most series except for the study by Pasic et al. (42). They analyzed data from the Premier hospital database of 358 hospitals in USA and found the use of robotic assistance was consistently associated with higher per-patient average hospital costs (14). Recently, Landeen et al. (59) analyzed the clinical and cost comparisons for hysterectomy via abdominal, standard laparoscopic, vaginal and robot-assisted approaches and demonstrated the highest complication rates for abdominal procedure and significantly greater blood loss and longer hospital stay with standard laparoscopic hysterectomy compared to robotic-assisted. Scandola et al. (60) in 2011 also reported a metaanalyses about robotic-assisted hysterectomy versus traditional laparoscopic hysterectomy and concluded that robotic-assisted hysterectomy has less deleterious effect on hospital, society, and patient stress and leads to better intervention quality. No randomized controlled trial has been published to date and current medical data is immature to draw concrete conclusion for robotic-assisted hysterectomy. The need for randomized controlled trials to compare outcomes of robotic technology to other forms of MIS is a topic of debate.

\section{The complex and multifactorial nature of UF}

Clinical and molecular studies have demonstrated that UF are not a single entity but a clinically and genetically heterogeneous disease (56-59). Although earlier studies have traditionally focused on estrogen and progesterone as major risk factors, compelling evidence indicates that multiple etiological factors such as growth factors, profibrotic cytokines, and proinflammatory mediators also contribute to UF pathogenesis (45, 60-67). In addition, complex interlocking networks of signaling pathways that regulate cell proliferation and differentiation, apoptosis, angiogenesis, and ECM synthesis and remodeling are aberrantly regulated in UF and are characterized by built-in redundancy and biological buffering capacity. For instance, it has been reported that progesterone can function through activating the PI3K/Akt pathway independent of the classical PR pathway (68). Similarly, activation of the PI3K/Akt pathway leads to estrogen-independent activation of ER- $\alpha$, with phosphorylation of ER and subsequent upregulation of estrogen-regulated genes and resistance to aromatase inhibitors (69).

Successful treatment of a complex disease such as UF requires effective means to control the full biological network underlying the disease. However, these networks are typically robust to external perturbations, making it difficult to beneficially alter the dynamics by controlling a single target. In fact, multi-target therapeutics are often more effective compared to monotherapies, and combination drugs are commonly used for treating various complex diseases (70). Consequently, the currently used drugs for UF treatment which exclusively modulate a single target, typically either the estrogen or progesterone signaling pathways, are limited in their therapeutic effects. By contrast, multi-target drugs which simultaneously modulate multiple critical hubs in the network of the signaling pathways underlying UF pathogenesis should achieve robust and durable therapeutic effects. Thus, it is logical to rethink the current treatment paradigm for UF in the context of multi-target drugs. These agents would have improved therapeutic efficacy by their collective effects on multiple primary and compensatory or alternative pathways. In addition, these multi-target drugs will affect not only the fibroid cells, but also the tumor microenvironment which is a crucial regulator of tumor growth.

\section{Microtubules: master regulators for multiple signaling pathways in UF}

Identification of a "druggable target" that regulates multiple biological processes and signaling pathways involved in UF pathogenesis is the gateway for developing a multi-target polypharmacological drug for UF treatment. Compelling evidence indicates that almost every pathway critically involved in UF development and progression is functionally regulated by microtubule (MT) dynamics. MT serve as master scaffolds for a variety of active molecules and transcription factors involved in cell proliferation, differentiation, apoptosis, angiogenesis, and ECM synthesis and remodeling. In addition, MT function as molecular "rails" which regulate the intracellular localization and the activities of many transcription factors, including ER $\alpha$, PR, TGF- $\beta$, growth factors, and profibrotic cytokines (71-78). Studies from my laboratory and others have demonstrated that drugs which target MT dynamics dampen the signaling pathways of ER $\alpha$ (74, $75)$, PR (75), TGF- $\beta(79,80)$, connective tissue growth factor (CTGF) (81-84), proangiogenic factors, (85) and anti-apoptotic factors (86) by sequestering these transcription factors or their downstream effectors in a "repressive state" in the cytoplasmic compartment of the cells. Thus, owing to their crucial role in orchestrating many biological processes and signaling pathways relevant to UF development and growth, MT represent appealing targets for innovative development of anti-UF drugs. Without a doubt, MT-targeting drugs have met with excellent clinical success in the treatment of many fibrotic diseases $(72,79)$.

\section{Conclusion}

This review article addresses an important risk to women's health, as UF occur in $70-80 \%$ of women. UF are also a major 
health disparity issue, occurring 3-4 times more frequently in African Americans as compared to white women. UF substantially increase the risk of a number of significant health outcomes, such as pain, preterm labor, placental abruption, postpartum hemorrhage, and cesarean section (87). Despite the magnitude of the problem, there are currently no effective therapies for UF and hysterectomy remains the major and definitive treatment option, resulting in direct healthcare costs of over $\$ 2$ billion annually $(3,4)$ In addition, for women who desire to preserve their fertility, hysterectomy is not a viable option.

\section{Conflict of interest}

No conflict of interest was declared by the authors.

\section{References}

1. Lethaby A, Vollenhoven B. Fibroids (uterine myomatosis, leiomyomas). Clin Evid 2005; 14: 2264-82.

2. Laughlin SK, Schroeder JC, Baird DD. New directions in the epidemiology of uterine fibroids. Semin Reprod Med 2010; 28: 204-17. [CrossRef]

3. Cramer SF, Patel A. The frequency of uterine leiomyomas. Am J Clin Pathol 1990; 94: 435-8.

4. Flynn M, Jamison M, Datta S, Myers E. Health care resource use for uterine fibroid tumors in the United States. Am J Obstet Gynecol 2006; 195: 955-64. [CrossRef]

5. Parker WH, Einarsson J, Istre O, Dubuisson JB. Risk factors for uterine rupture after laparoscopic myomectomy. J Minim Invasive Gynecol 2010; 17: 551-4. [CrossRef]

6. Spies JB, Bradley LD, Guido R, Maxwell GL, Levine BA, Coyne $\mathrm{K}$. Outcomes from leiomyoma therapies: comparison with normal controls. Obstet Gynecol 2010; 116: 641-52. [CrossRef]

7. Mukhopadhaya N, De Silva C, Manyonda IT. Conventional myomectomy. Best Pract Res Clin Obstet Gynaecol 2008; 22: 677-705. [CrossRef]

8. Millo N, Boroditsky R, Lyons EA. Fibroids treated with uterine artery embolization: do imaging findings correlate with patient outcomes? J Obstet Gynaecol Can 2010; 32: 460-6.

9. van der Kooij SM, Hehenkamp WJ, Volkers NA, Birnie E, Ankum WM, Reekers JA. Uterine artery embolization vs hysterectomy in the treatment of symptomatic uterine fibroids: 5-year outcome from the randomized EMMY trial. Am J Obstet Gynecol 2010; 203: 105.e1-13.

10. Hald K, Noreng HJ, Istre O, Kløw NE. Uterine artery embolization versus laparoscopic occlusion of uterine arteries for leiomyomas: long-term results of a randomized comparative trial. J Vasc Interv Radiol 2009; 20: 1303-10. [CrossRef]

11. Muzii L, Boni T, Bellati F, Marana R, Ruggiero A, Zullo MA, et al. $\mathrm{GnRH}$ analogue treatment before hysteroscopic resection of submucous myomas: a prospective, randomized, multicenter study. Fertil Steril 2010; 94: 1496-9. [CrossRef]

12. Sankaran S, Manyonda IT. Medical management of fibroids. Best Pract Res Clin Obstet Gynaecol 2008; 22: 655-76. [CrossRef]

13. Craig MC, Fletcher PC, Daly EM, Picchioni MM, Brammer M, Giampietro V, et al. A study of visuospatial working memory pre- and post-Gonadotropin Hormone Releasing Hormone agonists (GnRHa) in young women. Horm Behav 2008; 54: 47-59. [CrossRef]
14. Sherwin BB, Tulandi T."Add-back" estrogen reverses cognitive deficits induced by a gonadotropin-releasing hormone agonist in women with leiomyomata uteri. J Clin Endocrinol Metab 1996; 81: 2545-9. [CrossRef]

15. Wilson AC, Meethal SV, Bowen RL, Atwood CS. Leuprolide acetate: a drug of diverse clinical applications. Expert Opin Investig Drugs 2007; 16: 1851-63. [CrossRef]

16. De Falco M, Pollio F, Pontillo M, Ambrosino E, Busiello A, Carbone IF,et al. GnRH agonists and antagonists in the preoperative therapy of uterine fibroids: literature review. Minerva Ginecol 2006; 58: 553-60.

17. Weiss JM, Diedrich K, Ludwig M. Gonadotropin-releasing hormone antagonists: pharmacology and clinical use in women. Treat Endocrinol 2002; 1: 281-91. [CrossRef]

18. Stein K, Ascher-Walsh C. A comprehensive approach to the treatment of uterine leiomyomata. Mt Sinai J Med. 2009; 76: 546-56. [CrossRef]

19. Ouzounian S, Bouchard P, Chabbert-Buffet N. Effects of antiprogestins on the uterus. Womens Health (Lond Engl) 2008; 4: 269-80. [CrossRef]

20. Williams AR, Critchley HO Osei J, Ingamells S, Cameron IT, Han $\mathrm{C}$ Chwalisz K. The effects of the selective progesterone receptor modulator asoprisnil on the morphology of uterus tissues after three months treatment in patients with symptomatic uterine leiomyomata. Hum Reprod 2007; 22: 1696-704. [CrossRef]

21. Spitz IM. Clinical utility of progesterone receptor modulators and their effect on the endometrium. Curr Opin Obstet Gynecol 2009; 21: 318-24. [CrossRef]

22. Wilkens J, Chwalisz K, Han C, Walker J, Cameron IT, Ingamells $\mathrm{S}$, et al. Effects of the selective progesterone receptor modulator asoprisnil on uterine artery blood flow, ovarian activity, and clinical symptoms in patients with uterine leiomyomata scheduled for hysterectomy. J Clin Endocrinol Metab 2008; 93: 4664-71. [CrossRef]

23. Varelas FK, Papanicolaou AN, Vavatsi-Christaki N, Makedos GA, Vlassis GD. The effect of anastrazole on symptomatic uterine leiomyomata. Obstet Gynecol. 2007; 110: 643-9. [CrossRef]

24. Attilakos G, Fox R. Regression of tamoxifen-stimulated massive uterine fibroid after conversion to anastrozole. J Obstet Gynaecol 2005; 25: 609-10. [CrossRef]

25. Hilário SG, Bozzini N, Borsari R, Baracat EC. Action of aromatase inhibitor for treatment of uterine leiomyoma in perimenopausal patients. J Clin Endocrinol Metab 2009; 94: 1752-6.

26. Carr BR, Marshburn PB, Weatherall PT, Bradshaw KD, Breslau NA, Byrd W, et al. An evaluation of the effect of gonadotropinreleasing hormone analogs and medroxyprogesterone acetate on uterine leiomyomata volume by magnetic resonance imaging: a prospective, randomized, double blind, placebocontrolled, crossover trial. J Clin Endocrinol Metab 1993; 76: 1217-23. [CrossRef]

27. Friedman AJ, Barbieri RL, Doubilet PM, Fine C, Schiff I. A randomized, double-blind trial of a gonadotropin releasinghormone agonist (leuprolide) with or without medroxyprogesterone acetate in the treatment of leiomyomata uteri. Fertil Steril 1988; 49: 404-9.

28. Taran FA, Brown HL, Stewart EA. Racial diversity in uterine leiomyoma clinical studies. Fertil Steril 2010; 94: 1500-3. [CrossRef]

29. Pakiz M, Potocnik U, But I. Solitary and multiple uterine leiomyomas among Caucasian women: two different disorders? Fertil Steril 2010; 94: 2291-5. [CrossRef] 
30. Okolo S. Incidence, aetiology and epidemiology of uterine fibroids. Best Pract Res Clin Obstet Gynaecol 2008; 22: 571-88. [CrossRef]

31. Brummer THI, Jalkanen J, Fraser J, Heikkinen AM, Kauko M, Mäkinen J, et al. FINHYST 2006-national prospective I-year survey of 5279 hysterectomies. Hum Reprod 2009; 24: 251522. [CrossRef]

32. Bonilla DJ, Mains L, Whitaker R, Crawford B, Finan M, Magnus M. Uterine weight as a predictor of morbidity after a benign abdominal and total laparoscopic hysterectomy. J Reprod Med J Reprod Med 2007; 52: 490-8.

33. Claerhout F, Deprest J. Laparoscopic hysterectomy for benign disease. Best Pract Res Clin Obstet Gynaecol 2005; 19: 357-75. [CrossRef]

34. Jacoby VL, Autry A, Jacobson G, Domush R, Nakagawa S, Jacoby A. Nationwide use of laparoscopic hysterectomy compared with abdominal and vaginal approaches. Obstet \& Gynecol 2009; 114: 1041-8. [CrossRef]

35. Rebeles SA, Muntz HG, Wieneke-Broghammer C, Vason ES, McGonigle KF. Robot-assisted total laparoscopic hysterectomy in obese and morbidly obese women. J Robotic Surg 2009; 3: 141-7. [CrossRef]

36. Pitter MC, Anderson P, Blissett A, Pemberton N. Roboticassisted gynaecological surgery-establishing training criteria; minimizing operative time and blood loss. Int J Med Robotics Comput Assist Surg 2008; 4: 114-20. [CrossRef]

37. Lenihan FR Jr, Kovanda C, Seshadri-Kreaden U. What is the learning curve for robotic assisted gynecologic surgery? J Minim Invasive Gynecol 2008; 15: 589-94. [CrossRef]

38. Payne TN, Dauterive FR. A comparison of total laparoscopic hysterectomy to robotically assisted hysterectomy: surgical outcomes in a community practice. J Minim Invasive Gynecol 2008; 15: 286-91. [CrossRef]

39. AAGL Advancing Minimally Invasive Gynecology Worldwide. AAGL position statement: route of hysterectomy to treat benign uterine disease. J Minim Invasive Gynecol 2011; 18: 1-3. [CrossRef]

40. ACOG Committee Opinin No.444. Choosing the route of hysterectomy for benign disease. Obstet Gynecol 2009; 114: 1156-8. [CrossRef]

41. Sarlos D, Kots LA. Robotic versus laparoscopic hysterectomy: a review of recent comparative studies. Curr Opin Obstet Gynecol 2011; 23: 283-8. [CrossRef]

42. Pasic RP, Rizzo JA, Fang H, Ross S, Moore M, Gunnarsson C. Comparing robot-assisted with conventional laparoscopic hysterectomy: impact on cost and clinical outcomes. J Minim Invasive Gynecol 2010; 17: 730-8. [CrossRef]

43. Kilic GS, Borahay M, Phelps JY. Introduction of Robotic Surgery: Pitfalls and Future. Text Book of Gynaecologic Oncology, 2nd Edition, Gunes Publishing, Ankara, 2011, pg.606-614.

44. Nezhat C, Lavie O, Lemyre M, Gemer O, Bhagan L, Nezhat C. Laparoscopic Hysterectomy with and without a Robot: Stanford Experience. JSLS 2009; 13: 125-8.

45. Shashoua AR, Gill D, Locher SR. Robotic-assisted total laparoscopic hysterectomy versus conventional total laparoscopic hysterectomy. JSLS 2009; 13: 364-9.

46. Bell MC, Torgerson JL, Kreaden U. The first 100 da Vinci hysterectomies: an analysis of the learning curve for a single surgeon. South Dakota Medicine 2009; 62: 91-5.

47. Kho R, Hilger W, Hentz J, Magtibay P, Magrina J. Robotic hysterectomy: technique and initial outcomes. Am J Obstet Gynecol 2007; 197: 113.e1-4.

48. Wattiez A, Cohen SB, Selvaggi L. Laparoscopic hysterectomy. Curr Opin Obstet Gynecol 2002; 14: 417-22. [CrossRef]
49. Brummer TH, Seppälä TT, Härkki PS. National learning curve for laparoscopic hysterectomy and trends in hysterectomy in Finland 2000-2005. Hum Reprod 2008; 23: 840-5. [CrossRef]

50. Visco AG, Advincula AP. Robotic gynecologic surgery. Obstet Gynecol 2008; 112: 1369-84. [CrossRef]

51. Nieboer TE, Johnson N, Lethaby A, Tavender E, Curr E, Garry $\mathrm{R}$, et al. Surgical approach to hysterectomy for benign gynaecological disease. Cochrane Database Syst Rev 2009; CD003677.

52. Liu H, Lu D, Wang L, Shi G, Song H, Clarke J. Robotic surgery for benign gynaecological disease. Cochrane Database Syst Rev 2012 Feb 15; 2: CD008978.

53. Candiani M, Izzo S, Bulfoni A, Riparini J, Ronzoni S, Marconi A. Laparoscopic vs vaginal hysterectomy for benign pathology. Am J Obstet Gynecol 2009; 200: 465-6. [CrossRef]

54. Weinberg L, Rao S, Escobar PF. Robotic surgery in gynecology: An updated systemic review. 2011; 2011: 852061.

55. Sarlos D, Kots L, Stevanovic N, Schaer G. Robotic hysterectomy versus conventional laparoscopic hysterectomy: Outcome and cost analyses of a matched case-control study. Eur J Obstetric Gynecol Reprod Biol 2010; 150: 92-6. [CrossRef]

56. Kilic GS, Moore G, Elbatanony A, Radecki C, Phelps JY, Borahay MA. Comparison of perioperative outcomes of total laparoscopic and robotically assisted hysterectomy for benign pathology during introduction of a robotic program. Obstet Gynecol Int 2011; 2011: 683703.

57. Geppert B, Lonnerfors C, Persson J. Robot-assisted laparoscopic hysterectomy in obese and morbidly obese women: surgical technique and comparison with open surgery. Acta Obstet Gynecol Scand 2011; 90: 1210-7. [CrossRef]

58. Giep BN, Giep HN, Hubert HB. Comparison of minimally invasive surgical approaches for hysterectomy at a community hospital: robotic-assisted laparoscopic hysterectomy, laparoscopic-assisted vaginal hysterectomy and laparoscopic supracervical hysterectomy. J Robot Surg 2010; 4: 167. [CrossRef]

59. Landeen LB, Bell MC, Hubert HB, Bennis LY, Knutsen-Larson SS, Seshadri-Kreaden U. Clinical and cost comparisons for hysterectomy via abdominal, standard laparoscopic, vaginal and robot-assisted approaches. S D Med 2011; 64: 197-9, 201, 203 passim.

60. Scandola M, Grespan L, Vicentini M, Fiorini P. Robot-assisted laparoscopic hysterectomy ve traditional laparoscopic hysterectomy: five metaanalyses. J Minim Invasive Gynecol 2011; 18: 705-15. [CrossRef]

61. Ishikawa H, Ishi K, Serna VA, Kakazu R, Bulun SE, Kurita T. Progesterone is essential for maintenance and growth of uterine leiomyoma. Endocrinology 2010; 151: 2433-42. [CrossRef]

62. Sudarshan S, Sourbier C, Kong HS, Block K, Valera Romero VA, Yang Y, et al. Fumarate hydratase deficiency in renal cancer induces glycolytic addiction and hypoxia-inducible transcription factor lalpha stabilization by glucose-dependent generation of reactive oxygen species. Mol Cell Biol 2009; 29: 4080-90. [CrossRef]

63. Chegini N. Proinflammatory and profibrotic mediators: principal effectors of leiomyoma development as a fibrotic disorder. Semin Reprod Med 2010; 28: 180-203. [CrossRef]

64. Joseph DS, Malik M, Nurudeen S, Catherino WH. Myometrial cells undergo fibrotic transformation under the influence of transforming growth factor beta-3. Fertil Steril 2010; 93: 1500-8. [CrossRef]

65. Eiser AR. Does over-expression of transforming growth factor-beta account for the increased morbidity in AfricanAmericans?: possible clinical study and therapeutic implications. Med Hypotheses 2010; 75: 418-21. [CrossRef] 
66. Norian JM, Malik M, Parker CY, Joseph D, Leppert PC, Segars $\mathrm{JH}$, et al. Transforming growth factor beta3 regulates the versican variants in the extracellular matrix-rich uterine leiomyomas. Reprod Sci 2009; 16: 1153-64. [CrossRef]

67. Lewicka A, Osuch B, Cendrowski K, Zegarska J, Stelmachów J. Expression of vascular endothelial growth factor mRNA in human leiomyomas. Gynecol Endocrinol 2010; 26: 451-5. [CrossRef]

68. Arslan AA, Gold LI, Mittal K, Suen TC, Belitskaya-Levy I, Tang MS, et al. Gene expression studies provide clues to the pathogenesis of uterine leiomyoma: new evidence and a systematic review. Hum Reprod 2005; 20: 852-63. [CrossRef]

69. Gu C, Zhang Z, Yu Y, Liu Y, Zhao F, Yin L, et al. Inhibiting the $\mathrm{PI} 3 \mathrm{~K} /$ Akt pathway reversed progestin resistance in endometrial cancer. Cancer Sci 2011; 102: 557-64. [CrossRef]

70. Ma CX, Crowder RJ, Ellis MJ. Importance of PI3-kinase pathway in response/resistance to aromatase inhibitors. Steroids 2011; 76: 750-2. [CrossRef]

71. Hopkins AL. Network pharmacology: the next paradigm in drug discovery. Nat Chem Biol 2008; 4: 682-9. [CrossRef]

72. Hellal F, Hurtado A, Ruschel J, Flynn KC, Laskowski CJ, Umlauf $\mathrm{M}$, et al. Microtubule stabilization reduces scarring and causes axon regeneration after spinal cord injury. Science 2011; 331: 928-31. [CrossRef]

73. Li Q, Martinez JD. P53 is transported into the nucleus via an Hsf1-dependent nuclear localization mechanism. Mol Carcinog 2011; 50: 143-52. [CrossRef]

74. Manavathi B, Acconcia F, Rayala SK, Kumar R. An inherent role of microtubule network in the action of nuclear receptor. Proc Natl Acad Sci U S A 2006; 103: 15981-6. [CrossRef]

75. Salama SA, Kamel MW, Botting S, Salih SM, Borahay MA, Hamed AA, et al. Catechol-o-methyltransferase expression and 2-methoxyestradiol affect microtubule dynamics and modify steroid receptor signaling in leiomyoma cells. PLoS One 2009; 4: e7356. [CrossRef]

76. Jordan MA, Wilson L. Microtubules as a target for anticancer drugs. Nat Rev Cancer 2004; 4: 253-65. [CrossRef]
77. Mitchison T, Kirschner M. Dynamic instability of microtubule growth. Nature 1984; 312: 237-42. [CrossRef]

78. Batut J, Howell M, Hill CS. Kinesin-mediated transport of Smad2 is required for signaling in response to TGF-beta ligands. Dev Cell 2007; 12: 261-74. [CrossRef]

79. Zhang D, Sun L, Xian W, Liu F, Ling G, Xiao L, et al. Low-dose paclitaxel ameliorates renal fibrosis in rat UUO model by inhibition of TGF-beta/Smad activity. Lab Invest 2010; 90: 436-47. [CrossRef]

80. Dai P, Nakagami T, Tanaka H, Hitomi T, Takamatsu T. Cx43 mediates TGF-beta signaling through competitive Smads binding to microtubules. Mol Biol Cell 2007; 18: 2264-73. [CrossRef]

81. Samarakoon R, Goppelt-Struebe M, Higgins PJ. Linking cell structure to gene regulation: signaling events and expression controls on the model genes PAI-1 and CTGF. Cell Signal 2010; 22: 1413-9. [CrossRef]

82. Samarakoon R, Higgins CE, Higgins SP, Higgins PJ. Differential requirement for MEK/ERK and SMAD signaling in PAI-1 and CTGF expression in response to microtubule disruption. Cell Signal 2009; 21: 986-95. [CrossRef]

83. Samarin J, Wessel J, Cicha I, Kroening S, Warnecke C, GoppeltStruebe M. FoxO proteins mediate hypoxic induction of connective tissue growth factor in endothelial cells. J Biol Chem 2010; 285: 4328-36. [CrossRef]

84. Steffan JJ, Williams BC, Welbourne T, Cardelli JA. HGF-induced invasion by prostate tumor cells requires anterograde lysosome trafficking and activity of $\mathrm{Na}+-\mathrm{H}+$ exchangers. J Cell Sci 2010; 123: 1151-9. [CrossRef]

85. Escuin D, Kline ER, Giannakakou P. Both microtubule-stabilizing and microtubule-destabilizing drugs inhibit hypoxiainducible factor-1alpha accumulation and activity by disrupting microtubule function. Cancer Res 2005; 65: 9021-8. [CrossRef]

86. Knipling L, Wolff J. Direct interaction of Bcl-2 proteins with tubulin. Biochem Biophys Res Commun 2006; 341: 433-9. [CrossRef]

87. Cook H, Ezzati M, Segars JH, McCarthy K. The impact of uterine leiomyomas on reproductive outcomes. Minerva Ginecol 2010; 62: 225-36. 